\title{
THE TIES THAT BIND: STORIES OF WOMEN IN PRISON WHO ARE MOTHERS TO OLDER ADULT CHILDREN
}

\section{Kelly Lockwood}

\section{Abstract}

\section{Biography}

Key Words

\section{Mothering, Imprisonment, Narrative, Adult children}

\section{INTRODUCTION}

Imprisonment has the potential to significantly impact mothering (Lockwood, 2017). For some women, imprisonment may present the opportunity to repair and rebuild fractured relationships with their children; however, for many, being separated from their children is constructed as the most difficult aspect of imprisonment (Crewe, Hulley \& Wright, 2017), with the potential to severely alter, disrupt or even terminate mothering (Lockwood, 2017; 2018). Available research highlights the importance of mothering in relation to women's adjustment to and experiences of imprisonment and upon their rehabilitation, resettlement and potential reunification (Baldwin, 2017; Lockwood, 2017, 2018; Shami and Kochal, 2008). However, consistent with prison policy and practice, available research tends to rely on narrow definitions that often construct motherhood in relation to younger children, under the age of 18 (Caddle and Crisp, 1997). Consequently, the stories, experiences and needs of mothers in prison with older adult children often remain unheard.

Contemporary boundaries between childhood and adulthood continue to evolve (Punch, 2003). Traditional markers, including completing school, leaving the family home, beginning a career, getting married, and becoming a parent, have historically been considered as indicators of successful transitions to adulthood (Shanahan, Porfeli, Mortimer \& Erickson, 2013). However, such demarcated life stages have more recently been rejected and explorations of individuals' perceptions of achieving an adult identity, indicates that 
transitions to adulthood are culturally and historically specific (Hammack and Toolis, 2014). They involve subjective processes based on many factors such as chronological age, gender, social roles, race, socioeconomic status and financial independence and are often negotiated and constructed in relation to others (Panagakis, 2014; Punch, 2003; Settersten, Hurstenberg \& Rumbaut, 2013). Focusing on Western transitions, existing research highlights increasingly lengthier and more varied transitions which mean the time it takes to become an adult has increased from previous generations (Panagakis, 2014; Shanahan et al, 2013), leading to longer parent-child relationships, characterised by new expectations and changing experiences (Lee, Zarit, S. and Rovine, 2016). Despite this, the longest period of the motherchild relationship can be in the adult years for both generations (Proulx and Helms, 2008). Available literature indicates that whilst mothering can change, it remains a significant role and identity for women as their children transition to and experience adulthood (Arendell, 2000; Gilligan, Suitor \& Pillemer, 2015). Therefore, it is imperative that understandings of mothering and motherhood, in relation to imprisonment, are also reconceptualised to enable us to hear about and value the lives, experiences and needs of mothers of older adult children.

The chapter is based on the feminist narrative principles of bringing the stories of often marginalised women to the centre of discussion in order to try to make sense of the stories they tell about their lives; with the assumption that 'it is through narrativity that we come to know, understand and make sense of the social world and it is through narratives and narrativity that we constitute our social identities' (Somers, 1994, p. 606). Specifically, this chapter focuses on the constructed meaning of motherhood for women in prison who are mothers to older adult children. When mothering becomes disrupted through critical events, such as imprisonment, storytelling can enable mothers to actively shape, account for and make sense of their changing situations, roles and identities'. However, what can and cannot be told and heard of motherhood and mothering is culturally, politically and socially bound 
(Lockwood, 2017: 2018). Stories are therefore informed by the dominant narratives that are available at the time of telling (Woodiwiss, Smith, Lockwood, 2017). For women in prison who are mothers to older adult children, their stories may be both facilitated and impeded by gendered expectations and dominant narratives of 'good mothering' along with the sociocultural (and organisational) definitions of 'mother'.

Focusing on the individual stories of mothers in prison and those who have recently been released from prison, within this chapter, I consider the way in which women story motherhood in relation to older adult children. Presenting three interrelated narratives; 'Mothering from a distance: stories of missing out on children's transitions to adulthood'; "Motherwork': stories of participating in mothering adult children'; and 'Role reversal': stories of receiving support from adult children', I consider the specific challenges and opportunities for mothers in prison with older adult children.

\section{STORYING MOTHERING AND IMPRISONMENT}

Being able to tell culturally recognisable and coherent mothering stories is an important element of motherhood (Miller, 2017; Lockwood, Smith \& Karpenko-Seccombe, 2019; Lockwood, 2017: 2018). Stories implicitly communicate something of the narrators' identities as mothers and are chosen to convey the way in which they want their lives to be recognised (Miller, 2017). However, these stories are not free to be told in any way but are informed by the range of and accessibility to the different narratives circulating at any given time (Woodiwiss et al, 2017). Culturally, politically, socially and historically bound, available narratives inform what is known and also what can and cannot be told of motherhood and mothering (Miller, 2017). Mothering narratives may be defined differently in particular societies and cultures or throughout different periods of time, yet, there is a strong expectation to be a 'good' mother, however that may be storied and understood (Pederson, 2016). Western narratives of 'good mothering' are primarily based on 'intensive 
mothering' (Hays, 1996) and are permeated with the moral imperatives associated with the ethics of care for children (May, 2008), shaping women's roles and identities as mothers. As such, mothering and motherhood remains largely understood in relation to younger children, with the stories of mothers with older adult children often remaining unheard.

A growing body of academic research serves to renegotiate understandings of motherhood to accommodate mothering of older adult children, enabling alternative and diverse narratives to emerge (Gower and Dowling, 2008; Francis-Connolly and Sytniak, 2008). Gower and Dowling (2008) note that prevalent Western narratives often relate to notions of 'separation and autonomy' and the idea that mothers are expected to 'let go' as their children 'fly the nest'. A culturally significant element of mothering is therefore the facilitation of children's transition to adulthood (Ankeny, Wilkins \& Spain, 2009). Where mothers are able to identify that their children have successfully achieved adult status, a more positive mothering identity is often able to be constructed (Smith, 2016). However, focusing on mother's experience of separation from their children as they transition to adulthood, Green (2010) concludes that their children's increased independence and absence in their lives can significantly impact mothering identities and sense of self.

Further research facilitates the reconceptualisation of 'intensive mothering' as an on-going process that continues to be an integral part of women's lives when their children have transitioned to adulthood (Batisai, 2017; Jones, 2014). In exploring the 'motherwork' of women with older adult children, Francis-Connolly and Sytniak (2015) highlight that good mothering often involves providing a listening ear, offering both financial and emotional support, and engaging in constant worry about their children. However, Smith (2016) highlights that providing significant financial, emotional and/or residential support for "difficult" adult children is often constructed as a violation of maternal expectations with a sense of anger, disappointment and self-blame. This body of research highlights the complex 
and nuanced experiences and understanding of mothering older adult children; yet we know little about the mothering of older adult children for women in prison.

For mothers in prison of younger children, existing research indicates that mothers often struggle to cope with and adjust to prison life (Loper and Tuerk, 2006). The emotional impact of separation from their children and the challenges to negotiating mothering from custody have equally been identified in existing research (Baldwin, 2017; Lockwood, 2017; 2018). Research has highlighted that through storytelling mothers in prison are able to account for and actively shape their changing roles and identities in order to present an acceptable self (Lockwood, 2017; 2018) despite the limitations and constraints of their situation. As such, the meanings attached to motherhood and mothering for women in prison are continuously being shaped.

\section{THE STUDY}

Central to this chapter is understanding the constructed meaning of motherhood for women in prison in relation to older adult children. I draw on existing empirical data from four different studies in which I have been involved; all studies related to women's imprisonment and/or the impact on children of having a parent in prison. The studies consist of an ESRC funded narrative study exploring the way in which mothers experience, understand and story imprisonment; an evaluation of an overnight visiting facility at an open women's prison; a Welsh Government funded project exploring homelessness and women prison leavers; and an NHS funded study exploring the impact on children of parental involvement in the criminal justice system. Each study was approved by the relevant University Ethics Panel and (where appropriate) NOMS (National Offender Management Service, now HMPPS ${ }^{1}$ ).

\footnotetext{
${ }^{1}$ Her Majesty's Prison and Probation Service
} 
The transcripts of each study were revisited and those where women identified as having 'adult' children were reanalysed. 'Adult' children were initially defined as those over the age of 18 , consistent with prison policy and practice. However, some of the mothers spoke of children aged 16 and 17, who met several of the markers associated with adulthood identified in the literature; for example, were no longer in full time education, were living alone and were financially independent. Therefore, the definition was expanded to include those over the age of 16. In total, this chapter draws on one-to-one interviews with 13 mothers; 10 of whom were currently serving a prison sentence and three who had recently been released. The women were diverse in relation to ethnicity, ages of children, length of sentence and contact with their children. All participants identified as mothers of birth children and had between one and nine children each. Seven women were mothers to older adult children only and six were mothers to a combination of both older adult and younger children at the time of interview. The mothers were serving sentences ranging from two weeks to a life sentence.

A thematic approach to narrative analysis (Fraser, 2004) was utilised. Exploring the emergent themes within the transcripts, women's accounts were considered in relationship to the broader social, political, structural and cultural context within which they were told (Doucet and Mauthner, 2008). The final step of the analysis incorporated a shift from a focus on individual transcripts to viewing the data set as a whole (Mauthner and Doucet, 1998). This process involved considering the similarities and differences within and across the women's stories to consider the types of stories told and opportunities and challenges storytelling creates in the construction of mothering.

\section{NARRATIVE FINDINGS}

\section{Mothering from a distance: stories of missing out on children's transitions to adulthood}

Consistent with existing research with mothers in prison with younger children, the stories drawn upon in this chapter highlighted an enduring sense of loss. Whilst some women spoke 
of the loss of everyday contact and sense of connectedness, central to many stories was the specific loss of being able to participate in or witness their children's transitions to and experiences of adult life. Domene, Socholotiuk \& Young (2011, p.274) indicate that both parents and adolescents often construct this period of transition as a joint endeavour, in which they "work together to formulate and pursue plans for the youth's future", ensuring a strong sense of independence. Storying a sense of being constrained in their opportunity to participate in this culturally significant period of mothering (Ankeny et al, 2009), served to highlight the pain and disruptive impact of imprisonment to their mothering.

Fi (mother to three younger children and one older, now adult son) spoke of the difficulty of not being able to be an active presence during her son's transition to adulthood. Speaking of her son's physical transitions, Fi suggested;

when I see him, you know, and he's got this unshaven kind of look, he's very dark, and hairy arms, and I'm thinking, 'oh my God', you know, 'this boy's now this man' (Fi).

Fi also spoke of her son's increased independence and autonomy as he transitioned to adulthood during her sentence, and the significant change this represented to her role as a mother and to her perceived future mothering role;

I've gotta accept, he's left home, but I kept thinking, once I'm out of here, we'll all be back together - but he's moved on and he's left home..., he's a man, but you know, that's the thing, for you in here, it's like everything stops still, I keep thinking I'll go outside and everything'll be the way it was before and [he] will still be, you know, my little boy and I will be able to tell him 'you're not doing this' or 'you are doing this' (Fi).

Fi's story illustrates that in contrast to available research, which suggests mothers and their children largely experience and negotiate the transition to adulthood together, for mothers in custody, the transition may not be experienced as a process in which they can participate, but can represent an abruption (Locock, Ziebland \& Dumelow, 2009), a sudden ending of their 
younger child and their associated mothering role. Fi constructs the mothering role that she had known as having ended and a significant loss.

Fi also illustrated a sense that her son's transition to adulthood had been accelerated owing to her imprisonment; "he's been thrown in at the deep end with this..., having to survive for himself". Similarly, Diane told of the additional responsibilities her daughter had taken on owing to her imprisonment, including living alone and managing the family home. For Diane, the level of independence imposed on her daughter was incompatible with her chronological age, as she stressed; “she's sixteen and she's out there on her own..., she's only just turned sixteen". Diane's perception that her daughter was "out there on her own" was a significant threat to her sense of being a good mother, as she told of feeling that she had "let her down".

Anne's daughter was seven years old when she was sentenced to life imprisonment. Anne (mother to one now older adult child) told of how her daughter struggled with the "transition from teenager to young adult" during her sentence. She suggested that "the things that come with" this transition are "difficult" for any young person, but that her daughter had “experienced things she probably shouldn't have" during this time owing to her imprisonment. Anne suggested;

The most unfortunate thing is she left school early..., at the age of sort of $15 . . .$, so left school with no qualifications, and erm, just living in different hostels and erm, she did get some jobs and work, and erm but then she had to pay her full way when she was working and the hostel's rent..., she was earning less than what she was having to pay out, so ultimately she ended up having to give up work..., it was so-so difficult, so difficult because the guilt I felt was horrendous, I still feel it to this day (Anne).

For Anne, her sense of guilt related to her imprisonment having catapulted her daughter into early adulthood and being limited in her ability to support her. Such stories highlight the continued significance of the mothering role to women as their children transition to adulthood. 
Mothers of adult daughters told of specific challenges as their children transitioned to motherhood and the associated restrictions on their grandmother role. Whilst some research has argued that new mothers and their own mothers may experience conflict during this time (Sims \& Rofail, 2013), Sheeran, Jones \& Welch (2015) suggest that women largely desire continued closeness in their relationship with their mothers as they transition to and experience new motherhood. The grandmother role, is therefore often constructed as an extension of the mothering role. The inability to provide this support and participate in this process owing to the constraints of imprisonment, was constructed as a significant loss for some of the mothers in this study.

Bethan (mother to both adult and younger children) spoke of her inability to support her daughter as she became a mother; "I'm going to be a Nanny..., [it's] not good, I'm not giving my children support..., only over phone calls and that's not good". Similarly, Anne spoke of her sense of loss at not being able to actively participate in being a grandmother; "my daughter..., she's just had a baby of her own..., it's my first grandchild..., it hurts me and it's upsetting because I'm not there". These stories highlight an awareness of, commitment to and significance of their continued mothering role. Constructing the need for proximity to their children in order to offer support, these stories are also indicative of women's sense of the continuation of 'intensive mothering' once their children have transitioned to adulthood (Batisai, 2017; Jones, 2014).

However, for others, stories of their daughters' transition to motherhood and their role as grandmother were complex. Anita (mother to both an adult daughter and a pre-school son), spoke of how she felt that her daughter had "missed out on having [her] around" in her early years of being a mum. Yet, on being sentenced Anita told of being preoccupied with the needs of her younger son and went on to recall; “God forgive me, I didn't even think of my daughter then because I'm thinking she's old enough" and "my granddaughter, oh God she 
didn't even come into it". Anita's story serves to indicate an awareness of the expectations of her role during her daughter's transition to and early experiences of parenthood whilst simultaneously rejecting them. Therefore, whilst mothering older adult children continues to be constructed as significant for women in prison, notions of adulthood can be drawn upon to reposition mothering priorities where younger children are involved.

\section{'Motherwork': stories of participating in mothering older adult children}

Many changes to and challenges of the mothering role during custody for women of older adult children were highlighted within the interviews. However, through narrative construction and reconstruction, the mothers in this research illustrated their continued contribution to and success of their mothering role despite the limitations of their situations. Consistent with research by Francis-Connolly and Sytniak (2015) 'worrying' was a key feature of the stories of women in prison in relation to 'doing' mothering with adult children. Although unable to physically participate in mothering, 'worrying' was framed as work that was actively engaged in as part of their mothering role. For mothers in prison, worrying can be exacerbated by the constraints and challenges imposed by their imprisonment; related stories were therefore also often characterised by uncertainty and guilt. Mothers spoke of worrying about the choices their children made in their absence; their emotional and physical well-being; and the potential harms they may come to with a perceived sense of their increased vulnerability owing to their imprisonment.

Highlighting the continued significance of her mothering role to her adult children, Jenny (mother to three adult children) told of her immediate 'worry' on being sentenced:

I didn't know what to do. I just couldn't come to the terms that I was going to be there for 20 months..., My daughters..., how was everybody going to cope without me?

Linda (mother to two adult children) told of how the relationship with her son broke down owing to her imprisonment. She told of worrying about "how he's going to cope" and went 
on to suggest; "what were happening with him..., that was on my mind all the time, so it were making me more anxious". Drawing on available narratives in relation to mothering older adult children (Gower and Dowling, 2008), Linda suggested that her family were telling her to "let go" and "cut the apron strings". However, this was inconsistent with Linda's mothering needs and the perceived expectations of her role in continuing to mother her son, as she suggested "it is hard, it is hard".

Other women spoke of worrying about specific issues their children were experiencing in their adult lives. Anne told of her daughter being in a violent relationship and being restricted in her inability to support her:

The relationship was really bad, he was aggressive towards her..., he'd hit her a few times..., she was frightened of him, oh and I felt my hands were just tied, I felt sick..., she went through a bit of a black time then ..., I was a bit worried about her..., so that was really difficult.

Supporting children with decisions about and challenges in their relationships is considered a key part of mothering children in the transition to adulthood (Domene et al, 2013). Available research suggests that mothers (Cichy, Lefkowitz, Davis \& Fingerman, 2013) and in particular mothers of daughters (Domene et al, 2013), express a sense of mothering achievement and fulfilment when they were comfortable with their children's relationships. Therefore, whilst witnessing their children's difficult relationships may be a 'worry' for any mother, as expressed by Anne, mothers in prison can feel like their 'hands are tied' and are restricted in their ability to offer support. For Anne, her 'worry' was exacerbated through her perception that owing to her imprisonment, her daughter was "vulnerable" and "insecure", leading her to make "bad decisions".

Some mothers also spoke of worrying about the impact of their imprisonment on their adult children's mental health and well-being. Julia's (mother to three adult daughters) sense of being unable to protect her daughters from the impact of her imprisonment represented a 
significant challenge to her sense of being a good mother, with ongoing worry about their well-being; "I just hated it, I couldn't shelter them from it, I've sheltered them all their life". Diane also told of worrying about her daughter's well-being. She suggested her daughter had been in a "very, very dark place" because of her imprisonment and "depression set in with her". Diane suggested that her daughter was "holding [it] all in..., because she doesn't want me to be worrying when I'm in here, and that makes me worry more". Stories of worrying served to highlight the disruptive impact of imprisonment for both mothers and their children, whilst emphasising worrying as a significant element of and contribution to 'motherwork'.

Women also told of how they actively responded to worrying about their children and the challenges experienced by their children during their time in custody. Julia, Diane and Linda all told of asking family and friends to 'keep check' (Lockwood, 2013) on their children during their sentence. Consistent with research by Francis-Connolly and Sytniak (2015), others spoke of the way in which they provided a "listening ear". Diane explained that she and her daughter "do a lot of talking about what's happened and why I'm here, and how she's feeling". Lyndsey (mother to two adult daughters and one younger daughter) suggested she had limited contact with her daughters whilst in custody, but told of how she participated in mothering, offering emotional support and guidance through writing letters to ensure "they don't end up like me";

writing letters to my daughter..., saying how I feel on paper, nice ways, I put down positive things to her, let her know I'm alright, not to worry..., and how much I really love her and all that lot.

Anne suggested she was able to utilise the "proper strategies" that she had developed through the therapeutic interventions she had engaged with during her sentence to "be there for [her] daughter..., and to try and be able to help her". Being able to offer her daughter emotional support was storied as key to Anne's sense of being a good mother throughout her sentence: 
I'd say all these years later that I've got a very strong close relationship with my daughter, probably even closer than I would have maybe if I'd had been outside and that's because all we've ever had is communication and I've not physically been there but I've emotionally been there all these years, and she's probably opened up and spoke to me more than she probably would've done.

Anne's story serves to illustrate the continuation of her mothering role through 'all these years' with her 'even closer' relationship with her daughter testament to her ongoing commitment and the strength of their maternal bond. In doing so, Anne emphasises her sense of mothering ability rather than impairment owing to imprisonment, in order to promote a more positive sense of self.

A further way in which the mothers in this study were able to construct a more positive mothering identity was through highlighting the ways in which their children had positively adapted and succeeded in their adulthood. Telling of their children's personal growth and perceived success served as evidence of the women's capacity as mothers (Cichy et al., 2013) and therefore functioned to enable women to reclaim their identities as good mothers; whilst equally challenging dominant narratives that construct their children as particularly susceptible to negative outcomes (Myers, Smarsh, Amlund-Hagen \& Kennon, 1999).

Consistent with existing research (Cichy et al., 2013; Smith and Lockwood, 2019), education and employment were often drawn upon in the women's stories to highlight their children's success. Rita (mother to one adult son and three younger children) spoke of her son's educational achievements and how, now at 17 years old, was at a college for "freaky genius children". Julia suggested she was "really proud" when her daughter secured a job whilst she had been in custody; and Linda also told of her son's achievements;

[son's] been to uni..., he's doing all right for himself, he's a team manager now at Asda, he started there when he left uni, started just working from 18 hours a week, driving vans, delivering, and he's worked his way up. 
Lynne (mother to adult children) expressed a sense of her children's achievements in adulthood; "they all have their own homes, all got jobs, all got cars". Telling of such achievements enabled Lynne to lay claim to her mothering success, despite her situation, as she went on to express: "so I've done something right..., I'm really proud of them..., they are doing well".

Lyndsey spoke of being "in and out of jail all [her] life" and that her daughters had largely been cared for by their grandparents in their childhood. Reflecting on her mothering experience, Lyndsey suggested "I know I've been a bad mum" and constructed her daughters' achievements in relation to being good mothers and in providing what she perceived to be a good family life:

mi daughters..., they're lovely girls..., one's two children, and other one, she's pregnant, she's got a flat..., and she's got a bloke, he works, and he's got a lovely house, and when she comes in at a certain time he wants his bath run, his tea, like proper mum and dad, and bless 'em, right good with their kids.

For others, such as Fi and Anne, their sense of their children's success was in how they had responded to the challenges of their imprisonment. In speaking of her 19-year-old son, Fi suggested:

He really is a nice boy and you know he's quite happy in his own skin, if you know what I mean, and just seems to take everything in his stride and he's quite rational, and really, he is really mature, you know, he's amazing, but it's probably because..., with this [imprisonment], you know, and having to take on board different emotions and things.

Similarly, Anne suggested her daughter:

has matured into such a lovely young girl, she's very stable..., you know she didn't go down the road of turning to drink and drugs which she could easily have done, to drown her sorrows.

Storying their children's success enabled the mothers to disrupt oppressive interpretations and put a distance between their adult children and the stigmatised identity of and the associated negative outcomes for children of prisoners (Myers et al, 1999). They also enabled 
the mothers to highlight their mothering achievements by indicating that they had raised successful adults. However, whilst telling stories of their children's perceived success often served to enable the teller to lay claim to 'good mothering', they were also sometimes difficult to reconcile with the shame and guilt associated with being a mother in prison. Although, Lynne suggested that her children were "doing well", she went on to say "I have to make them proud now, mum's a let-down". Similarly, after speaking of her children's perceived success as adults, Lyndsey suggested: "I just feel like..., they must be embarrassed about me" and went on to say "[I just need to] get mi head sorted to be a proper mum so mi kids aren't totally embarrassed about me.” Therefore, these stories were often conflicting, reinforcing whilst equally disrupting positive mothering identities.

Although some stories told of actively participating in mothering from prison or telling of their children's success to construct a more positive sense of self, others were characterised by a loss of hope and ongoing guilt, associated with negative consequences for their own mental health and well-being. Diane told of consistent worry about the ongoing impact of her imprisonment on her daughter and storied her future mothering role as doing "whatever it takes to make her whole again". Linda spoke of constant feelings of worry and consequent guilt, leading to her becoming increasingly isolated;

[I] just wouldn't come out of my cell unless I had to go out for my meal. I just wouldn't join in with anything, I wouldn't do nowt because I were worried about my family.

Linda went on to tell of how she "self-harmed", suggesting "I were just making marks on my arms and my legs..., I felt like committing suicide”. Julia also spoke about the impact of constant worry about her children;

I lost loads of weight [whilst in prison], I had nothing to eat..., I've been getting a lot of seizures again, I'm epileptic, and its stress that brings them on. 
Anne also suggested: 'I went through a really bad breakdown..., I just hit rock bottom and I just could not pick myself up..., I just felt so down'. Through the illustration of emotional pain and suffering, these stories serve to emphasise women's commitment to dominant mothering ideologies and the impact to their sense of self when their mothering becomes disrupted. However, they also illustrate the pervasiveness of dominant mothering narratives and how women can struggle to negotiate them in the context of imprisonment in order to construct a story to live with in the present.

\section{Role reversal : Stories of receiving support from adult children}

Listening to the stories of mothers of older adult children illustrates the ways in which women continue to participate in mothering and support their children in their adult lives. However, their stories also tell of the ways in which their adult children often provide them with ongoing support during their sentence. Available literature in relation to adult children providing support for their parents in the community, largely explores parental care giving in ageing societies (Leinonen, 2011) and therefore focuses on support for elderly and infirm parents. The research is often quantitative in approach focusing on care givers experiences rather than the parents' perceptions of receiving support (Lecovich and Lankri, 2002). Consequently, alternative and diverse stories of this relationship remain largely absent. The mothers in this research emphasised receiving practical, emotional, and financial support from their adult children, along with child care provision for their younger children. Such support was constructed as greatly appreciated and indicative of their continued bond with their children, yet sometimes at odds with the cultural norms of the mothering role of providing, rather than receiving support.

Accommodation is identified in existing research as a key method of support provided by adult children for their elderly/infirm parents in the community (Leinonen, 2011). For mothers in prison, adult children provided practical support in maintaining or securing 
accommodation for their release. Linda told of how her son "got made joint tenant" so that he could "take the house on board" when she was sentenced to custody. Helen (mother to both adult and younger children) suggested her tenancy was given to her son when she was sentenced and Diane also told of how her daughter had "had to fight to keep [their] house on". Lynne suggested that without the support of her adult children, she "definitely would have lost" her accommodation and spoke about the on-going support they had provided in protecting her property;

My children are keeping an eye on it [accommodation] while I'm in prison..., My children are checking on it 3 times a week just so the neighbours think there's somebody home.

When Lynne's tenancy was under threat, she told of how her children stepped in to sort it out;

problems with the council with paying the rent..., they needed the agreement to the flat, so the children brought it up, I signed it and it's gone back in but I was two months overdue like..., its only because my children have been having my letters, that's the only way I found out..., It's down to my children.

Others told of their children providing accommodation on their release from custody. Anita told of how she intended to live with her daughter as a "safety net"; and Lyndsey spoke of how her daughters had provided residential support on release from a previous sentence;

living at one daughter's for so long and then they'd had enough, so they were phoning other daughter, so I were back at other daughters, backwards and forwards wi' me suitcase.

The housing needs of women leaving custody is recognised as a significant issue with many women not having suitable and stable accommodation secured on release (Corston, 2007). The stories of mothers in prison with younger children often construct housing as a priority resettlement need in order to maintain contact with or regain custody of their children (Gorden et al, in print). In contrast, analysis of the stories from which this chapter has drawn highlight the role that adult children play in maintaining and or providing accommodation for 
their mothers' release. However, such stories also enable mothers to lay claim to good mothering by emphasising their children's ongoing support and commitment to their successful resettlement.

Other forms of practical support were also identified: some women told of how their children had intervened at the prison to ensure their well-being. Diane told of how her son stepped in to deal with her medication;

I was really ill as well and they weren't giving me my proper amount of medication which was making me more ill and then my son kicked off in a visit, demanded to see the $\mathrm{SO}^{2}$, and said "look at the state of my mum, she wasn't like this when she came in, you've took her medication off her and when I leave here I'm going straight to the Solicitors and then I'm going to the papers".

Jenny spoke of a visit which she broke down telling her daughter that she was feeling isolated; "Nobody's talking to me..., because I keep crying. They keep calling me 'cry baby". Jenny told of how her daughter "stood up" and made a "statement" and how "the whole visiting shut up": "Anybody makes my mother cry, they're going to have to answer to me because I'll box the lot of you". Available research has illustrated loss of choice and agency as one of the most significant gendered pains of imprisonment for women (Crewe et al, 2017; Rowe, 2011). For women who have managed complex adult responsibilities prior to custody, loss of autonomy can be particularly challenging (Rowe, 2011). Funk (2010) has highlighted that adult children's accounts of supporting ageing parents in the community tend to emphasise respecting parental autonomy and individual responsibility. However, for Jenny and Diane, stories of their children's assertiveness and of 'taking control' of their situations and standing up to authority indicated the lengths their children would go to ensure their

\footnotetext{
${ }^{2}$ Senior Officer
} 
well-being, which in turn enabled them to lay claim to good mothering through suggesting the strength of the ongoing bond.

Several women also spoke of how their children had provided emotional support during their sentence. Diane suggested her daughter had shown her "complete devotion" throughout her sentence and Linda suggested; "My daughter ..., she's been there for me..., she's always there for me". For some, such as Angela (mother to adult children), the support from their adult children was key to ensuring successful resettlement: "I would rather be where I know my sons will keep an eye on me and I will stay strong because of them".

Often contradicting dominant narratives of 'intensive mothering', stories of receiving support were also often echoed by a sense of failure in their mothering role and for the burden they had placed on their children. Lynne suggested that "[my children] send me money in" but went on to suggest "I am writing it all down so I can pay it back to them soon, they will have it back, every penny back, I write it down”. Similarly, Lyndsey’s story suggested an ongoing sense of burden as she told of her desire to reclaim her role as mother in order to "do sommat for them instead of them helping me". Therefore, stories of receiving support were multifaceted and conflicting; enabling women to lay claim to good mothering whilst simultaneously threatening it.

A further way in which older adult children supported their mothers during their custodial sentence was in providing care for their younger siblings. The question of who will care for their children during their sentence is an immediate challenge presented to many mothers (Lockwood, 2018). Consistent with research from Baldwin and Epstein (2017), where mothers in prison had a combination of both older adult and younger children, their older children sometimes became primary carer or contributed to the care of their younger siblings in their mothers' absence. 
Fi spoke of the way in which her son who was 17 years old at the time of her sentencing had initially wanted to care for his three younger siblings. Fi went on to tell of how owing to his "young age", she instead negotiated care of her younger children with a close family friend, with her son living independently. However, she told of how her older son continued to participate in the ongoing care of his younger siblings, sending money for their care, especially at key times, such as their birthdays or Christmas;

They all got what they wanted for Christmas..., [son] sent them money, bless him, he sent [friend] money, to help towards buying their Christmas presents.

Fi also spoke of how her son adopted a "fatherly" role offering emotional support and guidance;

looking out for the little ones as well, you know, and he does, when he's talking to them..., he's like right protective of what they know..., just the way he talks to them, it's like fatherly.

For Fi, her older son's 'parenting' role with her younger children was spoken of with great pride and constructed as indicative of the strength of their family unit. Fi's story claims successful mothering through assertion that she had successfully raised her son to become a caring adult with a sense of responsibility for his younger siblings.

In contrast, for Anita, the care of her younger son by her older daughter was storied as a constant source of internal conflict. Not believing that she would receive a custodial sentence, Anita told of how she; “didn't make no plans to say who's going to have my son or what's going to happen". Consequently, Anita told of negotiating her son's care in the immediacy of being sentenced. Amid external fractions between her son's father, grandparents, aunt and family friend, Anita told of feeling powerless as each option involved large geographical distances and diminished contact with and involvement in her son's life. Initially being cared for by a family friend, in order to regain some level of mothering autonomy, Anita instructed her daughter to "get up there and get your brother" and requested that she become his 
primary carer. Illustrating commitment to her mothering role, Anita constructed arranging her son's care as a battle in which she fought to secure the option that provided the most opportunity for her to be involved in his life and secure his return to her care on release. However, Anita's story indicated she felt conflicted and lived with a sense of guilt at having prioritised the needs of herself and her son over those of her adult daughter;

I never thought, thinking how is she going to cope sort of thing..., I kind of worried more about my son, you know, and I'm thinking 'she's just had a baby as well, so she's got her daughter to think about and now there's my son'.

Anita told of a sense of ongoing debt in which she felt the need to make it up to her daughter;

I'm blessed to have the support..., I say to my daughter "I'll make it up to you, you know, for looking after my son and stuff" and I'm always saying "thanks".

Stories relating to teenagers being cared for by older adult children also indicated conflict. Julia spoke of her teenage daughter being cared for by her older adult daughters in the family home. Julia went on to tell of how her "whole family got ripped apart", with her daughters "all fighting". Julia's teenage daughter "had to move out" and stay with a friend. Sibling disputes are common (Dunn, Deater-Deckard, Pickering \& Golding, 1999); although there is a paucity of research exploring sibling relationships in the transition through adolescence and into adulthood, Milevsky \& Heerwagen (2013) note that parents are often more disengaged with disputes during this time. However, as illustrated by Julia, for mothers in prison the disrupted relationship and consequent separation of her family was constructed as a source of great anxiety. This story served to affirm the significance of Julia's ongoing role in her daughters' lives and to the maintenance of the family unit, as she suggested; "if I was there that would never have happened. Never".

Diane also told of a breakdown in the relationship between her children throughout her imprisonment. At the time of sentence, Diane's older son was twenty-seven years old, with her daughter sixteen and in her final year at school. Diane had originally asked her son to 
"look after his sister". For Diane, this arrangement was constructed as a source of comfort, as she suggested; "I came to prison thinking 'she's alright, she's safe"”. Diane suggested the relationship between her children, which she described as always being "very close" prior to her sentence, became significantly fractured. Explaining the relationship breakdown as owing to her son's chaotic lifestyle and substance misuse, Diane told of how her "son was really, really awful to [daughter]" and how her daughter was now "on her own in [their] house". The dispute was constructed as a source of great distress for Diane with ongoing worry about the implications for her daughter's well-being (as previously discussed on page?). However, Diane also framed her story against a narrative of anticipated filial support, with a sense of being let down by her son. Leinonen (2011) notes that family ties and obligation are constructed and negotiated across the life course and are shaped by and within individual and familial biographies. Diane suggested that "I've never asked my son to do anything for me it's always been me that's stood by him", going on to say; "[it was] the only thing I asked him to do". Diane's full story provided detailed accounts of the way in which she had "stood by" her son; reiterating the point here and evaluating it against the lack of reciprocated support served to illustrated the disruption to her familial relationships as she concluded that her son was no longer "on the scene" and she no longer had visits from him.

\section{CONCLUDING THOUGHTS}

In times of disruption, storytelling can function to help individuals make sense of and account for their changing situations roles and identities; narratives are therefore constructed and reconstructed to accommodate the changing self and position in the social world. As such, understandings of motherhood and mothering are continuously evolving. Drawing on feminist narrative principles of bringing the stories of marginalised groups to the centre of discussion, this chapter builds on existing research with mothers in prison, highlighting three interrelated stories, to specifically explore the constructed meaning of motherhood for 
women in prison with older adult children.

'Mothering from a distance: stories of missing out on children's transitions to adulthood' tells of an enduring sense of loss at the inability to participate in or witness children's transitions to and experiences of adult life. Consistent with existing research, this narrative has highlighted that mothering remains a significant role and identity for women with adult children (Arendell, 2000; Gilligan et al, 2015) with imprisonment representing a significant threat to their sense of self. These stories tell of missing out on their children's transition to and experiences of adulthood, with a sense of guilt at having accelerated this process and of not being able to offer support and guidance. However, these stories equally illustrate the complexity of meanings attached to mothering older adult children, with notions of adulthood sometimes drawn upon to reposition mothering priorities in relation to younger children.

'Motherwork': stories of participating in mothering adult children' illustrates that through constructing 'worrying' as 'motherwork' (Francis-Connolly and Sytniak, 2015), women in prison with older adult children continue to mother intensively. These stories also emphasised women's agency and capacity to participate in mothering and support their children despite the limitations of their situations. Speaking of their children's resilience and achievements in adulthood, also enabled the construction of a positive sense of being a mother and validation of their mothering role. However, for some women, narrative construction and reconstruction was significantly impeded by an enduring sense of guilt, with associated implications for their mental well-being.

'Stories of receiving support from adult children' tells of the practical, emotional and financial support mothers receive from their adult children during custody, along with child care provision for their younger children. Such support was valued and constructed as indicative of the continued bond with their children, yet also often at odds with the cultural norms of the mothering role of providing, rather than receiving support. However, where 
support was not forthcoming, a sense of being 'let down' was highlighted by women, with implications for the relationship between the mother and her older children.

Listening to the stories of women in prison with older adult children illustrates the need for a broader families' approach to prison policy that understands and responds to the mothering needs of women with older adult children. The stories equally highlight the role that older adult children play in supporting mothers in prison. Such stories are consistent with emerging policy rhetoric that positions families as a 'resettlement agency' (Booth, this collection); yet it is imperative that the policy rhetoric is matched with adequate provision of services to support the needs of families to enable them to continue to support their family member in custody.

\section{Acknowledgements}

I would like to thank the women who shared their stories with me. I would also like to acknowledge the funders for the research from which this chapter has drawn. Economic and Social Research Council (United Kingdom) (ES/I902597/1); University of Huddersfield; Welsh Government (C200/2016/2017); NHS Greater Glasgow and Clyde (GGC0472).

\section{REFERENCES}

Arendell, T. (2000) Conceiving and investigating motherhood. Journal of Marriage and Family, 62(4), 1192-1207.

Ankeny, E., Wilkins, J. and Spain, J. (2009) 'Mothers' Experiences of Transition Planning for Their Children with Disabilities'. Teaching exceptional children. 41(6), 28-36.

Baldwin, L. (2017) Motherhood disrupted: Reflections of post- prison mothers. Emotion, Space and Society. 26, 49-56. 
Baldwin, L. and Epstein, R. (2017). Short but not Sweet: a study of the impact of short custodial sentences on mothers and their children. Leicester: DeMontfort University.

Batisai, K. (2017) 'Pushing the limits of motherhood: Narratives of older women in rural Zimbabwe', African Studies, 76(1), 44-63.

British Sociological Association (2017) 'Statement of ethical Practice'. British Sociological Association. Retrieved January 14, 2018 from https://www.britsoc.co.uk/media/24310/bsa_statement_of_ethical_practice.pdf Caddle, D. and Crisp, D. (1997) Imprisoned Women and Mothers London: Home Office Cichy, K.E., Lefkowitz, E.S., Davis, E.M., \& Fingerman, K.L. (2013) “"You are such a disappointment!': Negative emotions and parents' perceptions of adult children's lack of success'. Journals of Gerontology, Series B: Psychological Sciences and Social Sciences, 68(6), 893-901.

Corston, J. (2007) The Corston Report. A report by Baroness Jean Corston of a review of women with particular vulnerabilities in the criminal justice system. Home Office. Available at: http://criminaljusticealliance.org/wp-content/uploads/2017/07/Corston-report-2007.pdf

Crewe, B., Hulley, S. and Wright, S. (2017) 'The Gendered Pains of Life Imprisonment'. The British Journal of Criminology, 57(6), 1359-1378.

Domene, J. Socholotiuk, K. \& Young, R. (2011) 'The Early Stages of the Transition to Adulthood: Similarities and Differences between Mother- Daughter and Mother-Son Dyads', Qualitative Research in Psychology, 8(3), 273-291.

Doucet, A. and Mauthner, N. (2008) 'What can be known and how?: narrated subjects and the listening guide'. Qualitative research, 8(3), 399-409. 
Dunn, J., Deater-Deckard, K., Pickering, K. and Golding, J. (1999) 'Siblings, Parents, and Partners: Family Relationships within a Longitudinal Community Study'. The Journal of Child Psychology and Psychiatry. 40(7), 1025-1037.

Francis-Connolly, E. and Sytniak, K. (2015) 'Mothering work and emerging adult children'. Work. 50(3), 465-472.

Fraser, H. (2004). 'Doing Narrative Research: Analysing Personal Stories Line by Line'. Qualitative Social Work, 3(2), 179-201.

Funk, L. (2010) 'Prioritizing parental autonomy: Adult children's accounts of feeling responsible and supporting aging parents'. Journal of Aging Studies. 24, 57-64.

Gilligan, M., Suitor, J. and Pillemer, K. (2015) 'Estrangement Between Mothers and Adult Children: The Role of Norms and Values'. Journal of Marriage and Family, 77(4), 908-920.

Gower, M. and Dowling, E. (2008) 'Parenting adult children - invisible ties that bind?'. Journal of Family Therapy. 30(4), 425-437.

Green, T. (2010) Motherhood, absence and transition: When adult children leave home. London: Routledge.

Hammack, P. and Toolis, E. (2014) Narrative and the social construction of adulthood. New Dir Child Adolesc Dev, 145, 43-56.

Hays, S. (1996) The cultural contradictions of motherhood. New Haven, CT: Yale University Press.

Jones, A. (2014) 'Recomposing maternal identities: mothering young adult children'. In. O'Reilly, A. Mothers, Mothering and Motherhood Across Cultural Differences: A Reader. Demeter Press. 
Lecovich, E. and Lankri, M. (2002) 'Attitudes of elderly persons towards receiving financial support from adult children'. Journal of Aging Studies, 16(2), 121-133.

Lee, J., Zarit, S. and Rovine, M. (2016) 'The Interdependence of Relationships with Adult Children and Spouses'. Family Relations. 65, 342-353

Leinonen, A. (2011) 'Adult children and parental care-giving: making sense of participation patterns among siblings'. Ageing \& Society. 31(2), 308-327.

Lockwood, K. (2017) Listening to mum: narratives of mothers in prison. In Woodiwiss, J., Smith, K. and Lockwood, K. Feminist narrative research: Opportunities and challenges. London. Palgrave Macmillan.

Lockwood, K. (2018) Disrupted mothering: narratives of mothers in prison. In: Taylor, T. and Bloch, K. (Eds). Marginalised Mothers, Mothering from the Margins. Emerald Publishing.

Lockwood, K., Smith, K. and Karpenko-Seccombe, T. (2019) 'Rethinking Stories of Transnational Mothering with International Students'. Women's Studies International Forum.72, 17-24.

Locock, L., Ziebland, S. and Dumelow, C. (2009) 'Biographical disruption, abruption and repair in the context of Motor Neurone Disease'. Sociology of health and illness, 31(7), $1043-1058$.

Loper, A. and Tuerk, E. (2006) Contact between incarcerated mothers and their children: assessing parenting stress. Journal of offender rehabilitation, 43(1), 23-43.

Lowe, P. (2016). Reproductive health and maternal sacrifice: Women, choice and responsibility. London: Palgrave Macmillan. 
Mauthner, N. and Doucet, A. (1998) 'Reflections on a voice-centred relational method: analysing maternal and domestic voices'. In. J. Ribbens and R. Edwards (eds). Feminist dilemmas in qualitative research. London: Sage.

May, V. (2008) 'On being a 'good' mother: The moral presentation of self in written life stories'. Sociology, 42(3): 470-486.

Milevsky, A. \& Heerwagen, M. (2013) 'A Phenomenological Examination of Sibling Relationships in Emerging Adulthood'. Marriage \& Family Review, 49(3), 251-263.

Miller, T. (2017) Doing narrative research? Thinking though the narrative process. In Woodiwiss, J., Smith, K. and Lockwood, K. Feminist narrative research: Opportunities and challenges. London: Palgrave Macmillan.

Myers, B. J., Smarsh, T., Amlund-Hagen, K., and Kennon, S. (1999). 'Children of incarcerated mothers'. Journal of child and family studies, 8(1), 11-25.

Panagakis, C. (2014) 'Reconsidering adulthood: Relative constructions of adult identity during the transition to adulthood'. Advances in Life Course Research, 1-13.

Pederson, S. (2016) 'The good, the bad and the 'good enough' mother on the UK parenting forum Mumsnet'. Women's Studies International Forum. 59, 32-38.

Proulx, C. and Helms, H. (2008). 'Mothers' and fathers' perceptions of change and continuity in their relationships with young adult sons and daughters'. Journal of Family Issues, 29(2), 234-261.

Punch, S. (2003) 'Childhoods in the majority world: miniature adults or tribal children?' Socology, 37(2), pp. 277-295.

Rowe, A. (2011) 'Narratives of self and identity in women's prisons: stigma and the struggle for self-defintiion in penal regimes'. Punishment and society, 13, 571 
Settersten, R. Hurstenberg, F. and Rumbaut, R. (2013) On the Frontier of Adulthood: Theory, Research, and Public Policy. Chicago: The University of Chicago Press Books.

Shami, M. and Kochal, R. (2008) 'Motherhood starts in prison: the experience of motherhood among women in prison'. Family Process, 47(3), 323-340.

Shanahan, M. Porfeli, E., Mortimer, J. and Erickson, L. (2013) ‘Subjective Age Identity and the Transition to Adulthood When Do Adolescents Become Adults?' In: Settersten, R. Hurstenberg, F. and Rumbaut, R. On the Frontier of Adulthood: Theory, Research, and Public Policy. Chicago: The University of Chicago Press Books.

Sheeran, L., Jones, L. and Welch, A. (2015), 'Women's relationships with their own mothers in the early motherhood period', International Journal of Gender and Women's Studies. 3(1), 26-32.

Sims, M. \& Rofail, M. (2013) 'The experiences of grandparents who have limited or no contact with their grandchildren'. Journal of Aging Studies. 27(4), 377-386.

Somers, M. (1994) 'The narrative constitution of identity: a relational and network approach'. Theory and Society, 23(5), 605-649.

Smith, J. (2016) Mothering 'difficult' adult children in later life: how resources matter. The Gerontologist. 56(3), 277-277.

Thiele, D. and Whelan, T. (2008) 'The Relationship between Grandparent Satisfaction, Meaning, and Generativity'. The International Journal of Aging and Human Development. 66(1), 21-48.

Vallido, T., Wilkes, L., Carter, B. and Jackson, D. (2010) 'Mothering disrupted by illness: a narrative synthesis of qualitative research'. Journal of advanced nursing. 66, (7), 1435-1445. 
Woodiwiss, J., Smith, K. and Lockwood, K. (2017) Introduction: Doing Feminist Narrative Research. In Woodiwiss, J., Smith, K. and Lockwood, K. Feminist narrative research: Opportunities and challenges. London. Palgrave Macmillan. 